\title{
Covid-19: Trump says added deaths are necessary price for reopening US businesses
}

\author{
Owen Dyer
}

Montreal

A rise in mortality is a price worth paying to restart the US economy, President Trump has said, as many states flout advice from scientists and reopen beaches, cinemas, or hair salons while new coronavirus infections are still widespread.

Asked whether deaths would rise as states reopened their economies, the president said, "Hopefully that won't be the case. It could very well be the case."

"I'm not saying anything is perfect," Trump said while touring a mask factory in Phoenix, Arizona, on 6 May. "Will some people be affected? Yes. Will some people be affected badly? Yes. But we have to get our country open, and we have to get it open soon."

Wearing no mask as he toured the factory, the president added, "They have to open. And the people of our country should think of themselves as warriors." Media were quick to note the background music that played as he inspected a batch of masks: the theme from the 1973 James Bond movie Live and Let Die.

The "gating criteria" for reopening, which the White House announced three weeks ago, ${ }^{1}$ have not been mentioned further. A dozen states are forging ahead despite clearly failing to meet some of those requirements, such as a steady fall in daily new cases. None of them has the testing infrastructure that public health experts say is necessary to sustain reopening.

\section{New spike}

Current US figures show 1263224 cases of covid-19 and 74 809 deaths, although modelling projections have grown rapidly more pessimistic since lockdowns began lifting, pointing to well over 100000 deaths. New York's preferred model suggested that, of the states that are reopening their economies, the most vulnerable to a new spike would be Indiana, Tennessee, and Texas. ${ }^{2}$

Trump said this week that he was planning to end the coronavirus taskforce led by vice president Mike Pence, but he reversed the decision hours later after a backlash. "I had no idea how popular the taskforce is until actually yesterday," said Trump. He sought to redefine its role, however, as seeking ways to safely reopen the economy.

Speaking to reporters in the Oval Office about prolonging the restrictions, Trump said, "I don't think people will stand for it. The country won't stand for it. It's not sustainable."
Despite a flurry of anti-lockdown protests that Trump has supported, polls consistently show that US citizens broadly oppose reopening. ${ }^{34}$ But they also show a clear partisan divide: Democratic voters overwhelmingly support keeping most businesses closed for now, while Republican voters are evenly split on the question.

\section{Whistleblower complaint}

The president's pandemic response became the subject of a whistleblower complaint this week, from the demoted head of the agency charged with coordinating the search for a vaccine. Rick Bright had been transferred to a less influential post, he wrote in his complaint, because his agency "would only invest the billions of dollars allocated by Congress to address the covid-19 pandemic in safe and scientifically vetted solutions and it would not succumb to the pressure of politics or cronyism."

The complaint alleges that administration officials urged him to promote chloroquine, then being touted by Trump as a potential cure. It states: "The administration promoted it as a panacea and demanded that New York and New Jersey be 'flooded' with these drugs, which were imported from factories in Pakistan and India that had not been inspected by the FDA [Food \& Drug Administration]."

The complaint also alleges that Bright warned senior officials known as the Disaster Leadership Group on 7 February of a coming shortage of masks but was told that his concerns were unwarranted and that no action was needed.

US Government, CDC. Guidelines for opening up America again. 16 Apr 2020. https:// www.whitehouse.gov/openingamerica/.

2 Yamana T, Pei S, Shaman J. Projection of covid-19 cases and deaths in the US as individual states re-open. 4 May 2020. http://www.columbia.edu/ jls106/yamana_etal reopening_projections.pdf.

3 Lazer D, Baum MA, Ognyanova K, Della Volpe J. Covid-19 Consortium for Understanding the Public's Policy Preferences Across States. The state of the nation: a 50-state covid-19 survey. 30 Apr 2020. https://covidstates.org/.

4 Balz D, Guskin E. Americans widely oppose reopening most businesses, despite easing of restrictions in some states, Post-U Md poll finds. Washington Post 2020 May 5. https: //www.washingtonpost.com/politics/americans-widely-oppose-reopening-most-businessesdespite-easing-of-restrictions-in-some-states-post-u-md-poll-finds/2020/05/04/495ddc3a8e36-11ea-9e23-6914ee410a5f story.html.

5 Bright R. US Office of Special Counsel Complaint \& Disclosure. 20 Apr 2020. https://www. documentcloud.org/documents/6882607-OSC-Complaint-Redacted.html\#document/p3.

Published by the BMJ Publishing Group Limited. For permission to use (where not already granted under a licence) please go to http://group.bmj.com/group/rights-licensing/ permissions 